\title{
ПОЛИФТОРАЛКИЛСОДЕРЖАШИЕ ПИРАЗОЛЫ КАК УНИВЕРСАЛЬНАЯ ПЛАТФОРМА ДЛЯ СОЗДАНИЯ БИОАКТИВНЫХ СОЕДИНЕНИЙ
}

\section{В.И. Салоутин, Е.В. Щегольков, Н.А. Агафонова, О.Г. Худина,}

\author{
Н.А. Елькина, Я.В. Бургарт
}

Институт органического синтеза им. И.Я. Постовского УрО РАН, 620990, Россия, Екатеринбург, ул. С. Ковалевской/Академическая, 22/20.

DOI: 10.19163/MedChemRussia2021-2021-20

E-mail: saloutin@ios.uran.ru

Пиразольный структурный мотив является признанным привилегированным скаффолдом медицинской химии, поскольку на его основе создан большой ряд лекарственных препаратов с различными фармакологическими эффектами.

В докладе обсуждается методология создания биоактивных соединений на основе полифторалкил-содержащих пиразолов с привлечением различных методов химических трансформаций. Показана возможность модификации пиразольного каркаса по всем положениям. Приведены экспериментальные данные по тестированию биологических свойств производных пиразола. Определены соединения-хиты с антибактериальным, антимикотическим, антиоксидантным, противоопухолевым, анальгетическим действием. Установлены закономерности «структура - активность», которые могут быть полезны для дизайна лекарственных препаратов на основе пиразольного скаффолда.

\section{Возможности химической модификации} пиразольного остова:

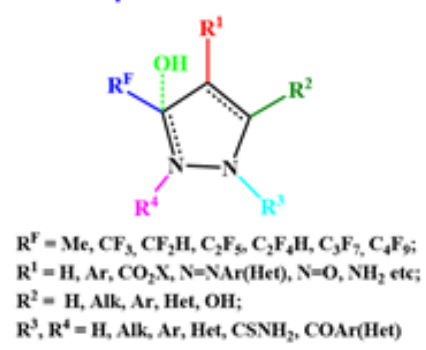

Биологическое действие:

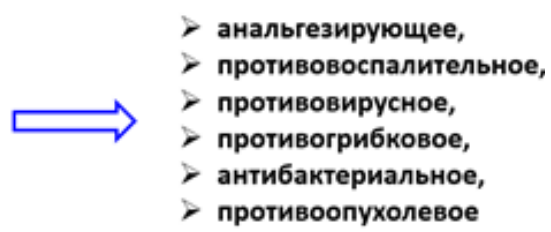

Работа выполнена при финансовой поддержке РНФ, грант 21-13-00390. 